\title{
A DESORDEM DO AMOR-PRÓPRIO SEGUNDO O PENSAMENTO DE LOUIS LAVELLE
}

\author{
José Aparecido Pereira ${ }^{1}$ \\ Pontifícia Universidade Católica do Paraná (PUCPR) \\ (iD) https://orcid.org/0000-0002-4718-2118 \\ E-mail: aparecido.pereira@pucpr.br \\ Harlon Luan dos Santos ${ }^{2}$ \\ Pontifícia Universidade Católica do Paraná (PUCPR) \\ https://orcid.org/0000-0001-5308-3653 \\ E-mail: harlon.l.mariahelena@gmail.com
}

\section{RESUMO:}

O presente artigo tem como tema principal a desordem do amor-próprio, conforme o pensamento de Louis Lavelle. Para esse filósofo, o amor-próprio é algo que não só macula a consciência do homem como também as suas relações com os outros. No egoísta há um processo de perca da consciência, visto que a ideia ou a imagem que tem de si é injusta à realidade, é sempre exagerada. Essa falsa imagem de si, por ser infundada, impede que sua consciência seja perfeita, impossibilitando, assim, um dos princípios básicos do filósofo: o conhecer-se a si mesmo. $\mathrm{O}$ artigo faz uma problematização do amor-próprio, apoiado na noção de sinceridade para consigo mesmo. Essa sinceridade, só é possível quando há o desapego das fantasias, ou seja, o desapego à vaidade. A reflexão realizada neste artigo se orientou pela leitura, análise e interpretação de textos de Lavelle, tais como, O erro de Narciso, Conduite à l'égard d'autrui, Traité des valeurs, De l'Acte.

PALAVRAS-CHAVE: Amor-próprio; Lavelle; Desordem; Narciso.

\section{THE DISORDER OF SELF LOVE ACCORDING TO THINKING OF LOUIS LAVELLE}

\begin{abstract}
:
This article has as its main theme the disorder of self-love, according to the thought of Louis Lavelle. For this philosopher, self-love is something that not only tarnishes man's conscience but also his relationships with others. In the egoist there is a process of losing consciousness, since the idea or image that he has of himself is unfair to reality, it is always exaggerated. This false self-image, for being unfounded, prevents your conscience from being perfect, thus making it impossible for one of the philosopher's basic principles: to know oneself. The article discusses self-love, supported by the notion of sincerity towards oneself. This sincerity is only possible when there is detachment from fantasies, that is, detachment from vanity. The reflection carried out in this article was guided by the reading, analysis and interpretation of texts by Lavelle, such as The error of Narcissus, Conduite à l'égard d'autrui, Traité des valeurs, De l'Acte.
\end{abstract}

KEYWORDS: Self-love; Lavelle; Disorder; Narcissus.

\footnotetext{
${ }^{1}$ Doutor(a) em Filosofia pela Pontifícia Universidade Católica de São Paulo (PUC/SP), São Paulo - SP, Brasil. Professor da Pontifícia Universidade Católica do Paraná (PUCPR), Maringá - PR, Brasil.

${ }^{2}$ Graduado(a) em Filosofia pela Pontifícia Universidade Católica do Paraná (PUCPR), Maringá - PR, Brasil.
}

PEREIRA, José Aparecido; SANTOS, Harlon Luan dos. A desordem do amor-próprio segundo o pensamento de Louis Lavelle. Griot : Revista de Filosofia, Amargosa - BA, v.22 n.1, p.157-167, fevereiro, 2022. 


\section{Introdução}

As defluências e ponderações que surgem em torno do problema do amor-próprio desregrado é amplo. Egoísmo, vaidade e, acima de tudo, injustiça. Todos esses conceitos têm uma mesma matriz. Por se tratar de uma paixão, o amor de si pode-se converter em vício assim como qualquer outra paixão. Uma vez convertido em patologia, o amor-próprio afeta diretamente a consciência, de tal modo que o sujeito perde a consciência das outras pessoas e sem perceber aos poucos vai perdendo a consciência de si mesmo. Louis Lavelle, filósofo da mente, fez uma detalhada reflexão acerca desse tema. A partir do mito de Narciso, Lavelle aponta detalhes que haviam passado despercebidos e que podem ser fundamentais a uma solução individual dessa desordem.

O objeto de reflexão deste artigo está relacionado à seguinte questão: por que, para Lavelle, o amor-próprio desregrado pode ser considerado narcótico? Para encontrarmos uma resposta à essa questão, foi necessário dividir o texto desta forma: a) A natureza do amor-próprio: partindo de uma contemplação do mito de Narciso, da fantasia de si e da vaidade do mostrar-se; b) A consciência entorpecida do soberbo e, c) A divergência entre o egoísmo e o desprendimento. A reflexão realizada neste artigo se orientou pela leitura, análise e interpretação de textos de Lavelle dos quais se destacam $O$ erro de Narciso, Conduite à l'égard d'autrui, Traité des valeurs, De l'Acte.

\section{A natureza do amor-próprio}

Primeiramente, é importante ressaltar que, de acordo com as obras de Lavelle, o amor de si é sinônimo de egoísmo. A princípio isso pode parecer sem sentido, contudo o filósofo faz considerações relevantes acerca da natureza do amor: o porquê ele é um sair de si, ao contrário do egoísmo que é um voltar-se ao próprio ego. Sendo assim, o amor-próprio em si é uma desordem. Não obstante, no decorrer do trabalho, exporemos de forma mais detalhada essa questão. De qualquer forma, não podemos negar que todos temos tendências egoístas. Por esse motivo, a seguir, veremos o motivo pela qual isso pode ser considerado pernicioso.

Se não fosse pela compulsão com que as pessoas buscam ser estimadas talvez não enquadraríamos o amor de si mesmo como uma das muitas patologias que existem na humanidade, pois não há homem que não tenha sofrido devido ao seu amor-próprio ou pelo dos outros. Por meios filosóficos, São Máximo Confessor (580-662) e posteriormente Pascal (16231662) entenderam que o amor desregrado de si é a causa de muitos males, senão de todos. Pode, entretanto, o amor a si mesmo causar mal? Para Aristóteles (2009) o amor de si não causa sofrimento, pois de acordo com ele o egoísmo, causa de males, é tudo menos amor-próprio, pois amor é o princípio da benevolência. Desse modo, os maus não têm sequer afeições por si mesmos, visto que não encontram neles mesmos nada que possa ser amável. Assim, para Aristóteles, o que faz com que os vis busquem coisas boas é a busca por prazeres ou a fuga de si mesmo. $O$ erro, nesse caso, não seria amar-se a si mesmo, mas amar-se apenas a si mesmo.

Contudo, o egoísta, em todas as circunstâncias se coloca acima de todas as coisas e pelo fato de isso ser constante e inalterável, o amor-próprio se torna um vício e, por isso, uma patologia. Aquele que têm suas ações motivadas pelo amor de si não necessariamente é malévolo. Acontece muitas vezes de grandes ações meritórias terem em sua essência a sede por ser honorificado. Diante disso, é difícil discernir o mote da ação: se é fruto da honestidade ou de um egocentrismo vicioso e disfarçado. Sobre isso, Louis Lavelle afirma: "Nunca olhar para trás para desfrutar do fruto da ação ou da ciência que se possui” (LAVELLE, 2011, p. 60). Esse olhar, segundo ele, está sempre 
envenenado por amor-próprio, e isso muda o valor da ação. Há somente uma alegria que é realmente pura. Ela não tem ligação nenhuma com os efeitos, mas sim com o próprio ato.

Qohélet há tempos avisa: "Vaidade das vaidades, tudo é vaidade" (BÍBLIA, 2012). De nada adianta se fixar na ilusão se ela é vazia e inexistente, não há, conforme fora dito por Ovídio (2010). O perigo da fixação na ilusão, e principalmente o perigo do amor-próprio já nos fora testemunhado por Narciso. Por isso, ele se tornou o personagem mais importante deste trabalho, pois por meio de uma contemplação filosófica do mito de Narciso, faremos um diagnostikós da filáucia: sua natureza e suas implicações.

\subsection{A contemplação de narciso, conforme Lavelle}

Dentre as várias versões da narrativa de Narciso, Louis Lavelle utiliza os poemas de Ovídio para uma contemplação acerca do torpor causado pelo amor-próprio no ser humano. Segundo o mito grego, os pais do menino Narciso consultaram Tirésias, o vidente, acerca do futuro da criança. Viu, pois, o mago, que o menino conheceria a velhice se não visse a si mesmo. Cresceu Narciso, mais belo entre os filhos dos homens. Cobiçado por mortais e imortais, recusava ao amor de todos. Dentre as muitas moças que se apaixonaram por Narciso conta-se a Ninfa Eco, a que mais sofreu por este amor: "Eco tinha então corpo, não só voz; porém, igual agora, a boca repetia, gárrula, entre tantas, somente as últimas palavras" (OVÍDIO, 2010, p. 100). Eco, apaixonada pelo belo jovem que via caçando, o deseja, mas o puro moço a ninguém se entregava em amor. Eco, amargurada, encerra-se em uma caverna e lá definha até que de si somente sobra o gemido de sua voz.

As jovens desprezadas por Narciso clamam vingança a Nêmesis, a deusa da justiça, e ela as ouve. Em uma manhã, Narciso, baqueado pela longa caça, aproxima-se de uma fonte para se saciar. No espelho aquático vê sua figura, apaixona-se por ela, e em uma espécie de vício se hipnotiza. Nada mais lhe encanta nem lhe prende a atenção senão a imagem que tem de si mesmo: "É sua beleza que produz agora o desejo que o atormenta, que o separa de si ao lhe mostrar sua imagem, e que o obriga a se buscar onde ele se vê, isto é, onde ele não é mais" (LAVELLE, 2012, p. 37). E ao se aproximar da água, caindo no simulacro de si, naquilo que tanto lhe assemelha, morre.

Narciso é mais lembrado pelo seu amor-próprio que pelos seus méritos. É que o primeiro é mais forte que o último. Por isso, deixa marcas mais resistentes. O mérito, segundo Louis Lavelle (2011), não disputa prestígio e reconhecimento. Quem faz isso é o amor-próprio. Um dos erros de Narciso, conforme o filósofo, foi confundir a simulação com o real. Esse é o vício de sua consciência. Juntando-se a isso a paixão, o vício se torna ainda mais inexorável. O jovem vê a imagem de si como fim em si mesmo, mas ele em Ato não é encontrado olhando para o externo. $\mathrm{O}$ jovem busca no simulacro um Ser que lá não está. O Ser está além de tudo que é visível: "Desse Ser não há imagem alguma" (LAVELLE, 2012, p. 51). O moço só pode entrar em contato com o Ser olhando para dentro de si e não olhando para a imagem externa de si.

Para contemplar sua própria imagem Narciso se afasta de si para melhor se ver e se lança em direção a si para se capturar. Foi preciso ao rapaz abandonar-se para dar à sua paixão um objeto, o qual se aniquilaria se se unisse a ele. Nessa aventura, só um pouco de água o separa de si mesmo. Aproxima-se, pois, das águas para capturar aquilo que não é senão uma imagem. Eis o seu drama: o que lhe é oferecido naquele momento é apenas a sua aparência (LAVELLE, 2016). Ante sua própria imitação, querendo conhecer-se melhor, Narciso busca aquilo que o lisonjeia e alegra e não o que ele é. Nesse sentido, o autor afirma o seguinte: 
Narciso não sabe que deve abandonar seu corpo para perceber sua imagem. Ele quis imitar Deus que, ao contemplar-se, criou $^{3}$ seu Verbo. E não pôde ver senão a imagem do seu corpo. Mas nela se vê mais belo que todos os espetáculos, e essa descoberta o faz desfalecer. Ele desaparece na fonte: pois quer que sua imagem muito bela ocupe todo o lugar do seu ser, como aconteceu a Lúcifer quando se tornou Satã. Narciso busca gozar pelo espírito da própria imagem do seu corpo. Empreendimento ousado e criminoso que só podia precipitar seu espírito (LAVELLE, 2016, p. 46).

Ao dizer que Narciso deve abandonar seu corpo para perceber sua imagem, Lavelle supõe que o homem só tem o direito de se contemplar quando já estiver pronto, ou seja, quando já tiver completado os seus dias de vida. Somente assim, conforme o autor, o homem estará completo e realizado. É que para ele a existência precede a essência: o homem nasce, existe, mas o seu ser, poderá ser afirmado apenas quando esse já estiver pronto, selado com a morte. Esse foi um dos erros de Narciso: ele procurou contemplar-se ainda na aurora de sua vida, antes de ter findado sua essência. Assim, precipitou-se tragicamente Narciso em falecimento, realizando, então, a sua vontade: contemplar sua essência. A imitação de si, que aparecia no espelho d'água ante o moço, era de uma beleza sedutora, porém aquela imagem, não tem essência própria, é ilusão:

Quantas vezes querendo abraçar a visão, na água os braços mergulhavam achando nada! Não sabe o que está vendo; mas ao ver se abrasa, e o que ilude os seus olhos mais o incita ao erro. Por que, em vão, simulacro fugaz buscas, crédulo? O que amas não há; se te afastas, desfaz-se. Isto que vês reflexo é sombra, tua imagem; nada tem de si (OVÍDIO, III, 2010, p. 103).

Hipnotizado por sua própria imitação, crê Narciso ser animada aquela réplica. Entretanto, tal réplica aparece para ele, mas não se parece consigo, pois não há a essência necessária. Por isso, no próximo tópico faremos uma abordagem sobre o ser em ato e sobre o simulacro como phantasma. Isso nos possibilitará fazer uma relação entre Louis Lavelle e Platão.

\subsection{0 eu como ato e como phantasma}

Lavelle (2014), em concórdia com a filosofia medieval, reafirma que o eu é ato. Assim, o homem se constrói, em sua vida e só se realiza completamente na morte. Desse modo, a essência do indivíduo são os seus valores. Sendo o eu um ato, não pode ser objeto, ente, mas poder que o mesmo exerce. Tarcísio Padilha (2012, p. 64) defende que a ação para o filósofo é uma das qualificações do Ser. Acerca disso, "[...] o próprio Lavelle reconhece que no De l'Acte há uma dinamização do ser". Giovanni di Napoli, fazendo um comentário sobre a possível passagem de Lavelle da ontologia para uma dinamização do Ser, faz o seguinte comentário: "Da doutrina da realidade como sendo (onto-logia) para a doutrina da realidade como um ato (dynami-logia)" (NAPOLI, apud. PADILHA, 2012, p. 64, tradução do autor).

Lavelle defende a tese da univocidade do Ser. Assim, o Ser, sendo ato, abarca tanto Deus como o homem. É o ato que possibilita tanto a física quanto a metafísica: “A metafísica repousa sobre uma experiência privilegiada que é a do ato que me faz ser" (LAVELLE, 2015, p. 16, tradução nossa). Aplicando essa tese na auto-realização humana o autor afirma:

\footnotetext{
3 Embora seja incorreto, segundo o cristianismo, dizer que o Pai criou o Verbo, Lavelle utiliza a palavra créé e não a palavra généré, comum ao cristianismo.
} 
Eu não sou nada mais que um ato que eu mesmo realizo interiormente, ato sempre em obra, mesmo quando eu não faço isto sozinho, e que, assim que eu participo, é sempre juiz de si mesmo e mediador entre conhecimento e força de vontade: é o coração o segredo da criação (LAVELLE, 2015, p. 17, tradução nossa).

Portanto, é na atualização que se forma a essência do ser. Para o autor, a existência precede a essência, pois de acordo com a univocidade do ser defendida pelo filósofo, primeiro há a existência, o ser, em seguida as essências individuais. ${ }^{4}$ A atualização é o modo de ser e o modo de se realizar. Cabe ao homem agir para se realizar. Narciso, conforme Lavelle, assim não o fez. Ele se reduziu a solicitação às cópias ao invés de ir ao original, que era o seu eu: "Se fosse verdade dizer que Narciso se duplicou, ele encontraria no seu duplo um fragmento de si mesmo. Mas, em vez de se desdobrar, ele duplica, para se ver, sua própria realidade invisível, e o que torna assim visível não é mais que uma sombra sem realidade" (LAVELLE, 2012, p. 43).

É na submersão da ilusão que Narciso se perdeu segundo Alfredo Bosi (2012). Ele supunha estar se conhecendo, mas na realidade não contemplava o real. O que via era simulacro e phantasma $^{5}$. Bosi, no prefácio da obra $O$ erro de Narciso, faz uma analogia da contemplação de Narciso e do diálogo do Estrangeiro com o Teeteto de Platão. Segundo ele, a imagem ou phantasma é o que parece e o que aparece ou se manifesta: phaneros. $O$ duplo que aparece, a cópia de si que se pode ver nos espelhos e na água, é considerado pelo Estrangeiro do diálogo no Teeteto como não verdadeiro ou não-ser (PLATÃO, 2007). Fazendo uma leitura do mito de Narciso à luz do diálogo com Teeteto é possível fazer alguns destaques. Lavelle os apresenta do seguinte modo: "Narciso se contenta numa imagem enganadora; é nela que faz agora sua morada e não no seu próprio ser. E o erro mais grave em que pode cair é que, ao criar essa aparência de si na qual se compraz, ele imagina ter criado seu ser verdadeiro" (LAVELLE, 2012, p. 41).

O autor caracteriza como natural ao amor-próprio essa busca por uma simulação e o desprezo pelo real. Há como que uma falsificação do eu em detrimento de um eidolon que mascara a realidade e faz com que haja a fuga do ser. Entretanto, se se vive em um mundo onde todas as coisas que são sensíveis e físicas aparecem e se aparentam reais, como distinguir o verdadeiro do falso? Lavelle responde que o modo pelo qual se pode conhecer e distinguir o verdadeiro do falso é indo além do que aparece e aparenta. É próprio da metafísica buscar o que está por trás do que aparece. Essa já é a função da reflexão segundo ele: "os sentidos se limitam a nos apresentar a aparência das coisas, enquanto a reflexão se aplica a essa aparência e se pergunta se ela não é ilusória" (LAVELLE, 2012, p. 146).

Para Lavelle a ocasião e o contexto em que a pessoa existe são assimilados à sua essência. Desse modo, a realidade que a circunda assim fora feita para que esse, por meio de seus meios atue. Em relação a isso o autor afirma: "É sempre inimigo de si preferir a ocasião que fizemos nascer à que nos foi dada" (LAVELLE, 2016, p. 81). É que o amor-próprio não se conforma com esses dados e meios, pois se cria uma simulação paralela à realidade onde os meios sejam outros. Isso se dá porque é incapaz de transformar tal ideia em ato. À vista disso, no tópico seguinte falaremos sobre a simulação de ideias ou ídolos que o amor-próprio cria para fugir da realidade. Também será abordado o tema da vaidade como exposição ou exibição de uma imagem de si que na realidade é uma imagem vã à pessoa.

\footnotetext{
${ }^{4}$ Embora se atribua a Sartre (1905-1980) a teoria de que a existência precede a essência, tendo como base o livro $O$ Ser $\boldsymbol{e}$ o nada, escrito em 1943, na primeira edição de De l'Acte (1937), Lavelle já defende essa teoria.

${ }_{5}^{5} \Phi \alpha ́ v \tau \alpha \sigma \mu \alpha$ : que aparece, mas não se assemelha ao real.
}

PEREIRA, José Aparecido; SANTOS, Harlon Luan dos. A desordem do amor-próprio segundo o pensamento de Louis Lavelle. Griot : Revista de Filosofia, Amargosa - BA, v.22 n.1, p.157-167, fevereiro, 2022. 


\subsection{O eidolon de si e a vaidade presente no se mostrar}

Lavelle apresenta dois tipos de homens: “os que só dão ouvidos ao amor-próprio e só pensam na imagem que oferecem de si mesmos, e os que não suspeitam que exista tal imagem, nem que ela possa diferir do que eles são" (LAVELLE, 2012, p. 72). Nessa oposição existente entre o ser e o aparecer Narciso opta pela aparição. Se de outro modo fosse, então não teria ele se deslocado para algo externo, mas havia feito uma interiorização, pois o eu real está atrás dos olhos, onde não se pode enxergar (LAVELLE, 2012). Entretanto, é preciso conhecer-se como disse Sócrates (469-399 a. C.), e isso, de acordo com o autor, apenas é possível pela reflexão e pela interiorização, isto é, por meio da intimidade consigo. Se não há essa intimidade também não haverá sinceridade para consigo mesmo. Não havendo sinceridade para consigo mesmo, a ideia ou ídolo que se tem de si nunca é justa à realidade (LAVELLE, 2012).

Ideia e eídolon têm a mesma raiz grega. ${ }^{6}$ Eidolon foi a palavra usada pelo Estrangeiro no diálogo com Teeteto para designar uma cópia de algo que descaracteriza as proporções reais para fazer com que uma arte se torne mais bela, não havendo aí uma sinceridade com a verdade e com a realidade (PLATÃO, 2007). No amor-próprio algo semelhante acontece: o narcisista adequa a imagem de si a algo que é alheio a sua realidade, que lhe é vão. Nasce, assim, a vaneidade ou vaidade: "A sinceridade é o princípio da vida moral e a fonte de todas as virtudes. Mas para isso, é preciso que ela não se contente com sua aspiração em uma espécie de narcisismo" (LAVELLE, 2016, p. 180), pois é próprio do amor-próprio criar simulações em que haja favorecimento de si, gozo e admiração: “É para obter gozo de si que ele faz de si mesmo um ídolo" (LAVELLE, 2012, p. 46).

O narcisista quer sempre ser um espetáculo e tem uma grande sede de admiração. É que ele só tem a aparência para oferecer. Só tem o mostrar-se, não conhece o fazer-se. Se, pois, a sinceridade é mostrar a realidade, logo faz parte da essência da sinceridade o se mostrar, mas a si mesmo. Quanto a isso, Lavelle faz a seguinte afirmação: "Ser sincero é mostrar-se, mas fazendose. Não é falar, mas agir" (LAVELLE, 2016, p. 74). A ficção simulada é um erro quando essa artificialidade se torna uma traição da realidade e da natureza pessoal. Não se dá mais importância ao seu modo de ser, mas prefere-se o que causará invídia nos demais.

Acerca disso, Christopher $\operatorname{Lasch}^{12}$ faz a seguinte afirmação:

\footnotetext{
A superexposição a ilusões fabricadas logo destrói seu poder de representação. A ilusão de realidade se dissolve, não em uma sensação exacerbada da realidade como poderíamos esperar, mas em uma notável indiferença pela realidade. Nosso senso de realidade parece repousar, bastante curiosamente em nosso desejo de ser envolvidos pela ilusão representada da realidade. (LASCH, 1983, p. 119).
}

A opção pela ilusão que lhe aparece e pelo espetáculo de si foi o meio pelo qual Narciso se alienou. Essa alienação tende a ser sempre constante até o ponto de não haver mais interioridade, sinceridade e sensatez. A consciência de si é esquecida e trocada pela simulação e pela dissimulação. A sinceridade, por sua vez, é trocada pela falsidade. Nesse estado a consciência de si se degenera e definha. Trataremos mais desse assunto no próximo tópico.

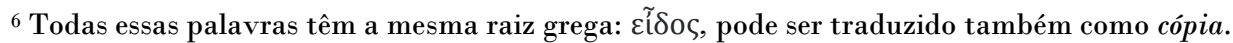




\section{A consciência entorpercida do soberbo}

Há, no mito de Narciso, alguém que embora apareça poucas vezes é muito importante na narrativa, aquela que queria melhor conhecê-lo, mas a quem o jovem não dera a menor atenção: a ninfa Eco. Ela, de acordo com Lavelle (2012), é uma figuração da consciência de Narciso. Eco busca conhecer e amar o belo jovem, mas esse a ignora. Ela não tem voz própria e pode repetir apenas fragmentos das palavras ditas por outros. Só poderia comunicar-lhe se ele por primeiro lhe comunicasse, mas Narciso não se importa em se comunicar com Eco, ou seja, com sua consciência. Eco, então completamente esquecida, definha no fundo de uma caverna, tal qual a consciência de uma pessoa que está totalmente hipnotizada pelo amor-próprio.

Assim, o amor-próprio gera a avareza e o orgulho. Isso porque o amor a si exagerado faz com que a pessoa se ufane daquilo que tem, tornando-se um soberbo. Para Lavelle (2012) tanto a avareza quanto o orgulho são considerados como vício e embriaguez. É como se o amor-próprio

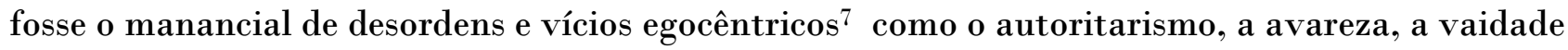
e a arrogância. Podemos observar, desse modo, que o egoísmo é um vício de si, ou melhor, um vício do triunfo de si, uma vez que a consciência fica entorpecida e tudo que seja alheio à pessoa se torna ignorável. Isso pode ser definido como narcose, termo que tem a mesma raiz grega donde deriva a palavra Narciso.

Se a consciência de si pode definhar quando Eco é esquecida, isso significa que o amorpróprio está afastado da consciência de si e mais próximo da fantasia de si. A consciência de si é a consciência do que se é. Quando não há essa consciência é que são confeccionadas as fantasias de si mesmo. Toda fantasia é para desconfigurar o que se é. Logo, o seu objeto não é o ser, mas o aparentar. No grande desafio de não só parecer, mas ser, unicamente os que são sinceros tanto consigo quanto para com os outros não veem aí diferenciação: "se sou dentro de mim o que devo ser, o serei também fora de mim" (LAVELLE, 2012, p. 71). Isso acontece porque quando há a sinceridade, a ação não tem como fim a busca por reconhecimento. Os vaidosos, em contrapartida, agem como se a aparência fosse além do ser. (LAVELLE, 2012).

Quando há a pureza de consciência não há a ficção. Toda ação é feita com simplicidade, pois é completamente real e sem desvio às ilusões. A pureza pode ser comparada à transparência. Quando há pureza, a consciência de si é autêntica. Uma consciência pura é livre, pois não está presa a si mesma e, por isso, está também aberta aos outros. Ela é consciência de si, mas também é consciência das outras pessoas. Assim, só uma consciência pura tem abertura para com outrem: "Bem-aventurados os que têm o coração puro, pois verão a Deus. Mas Narciso quer ver apenas a si mesmo" (LAVELLE, 2012, p. 202). Contudo, uma vida com boas aparências é o desejo de muitas pessoas, mesmo que o que apareça seja diferente da realidade. O homem faz horrores só para ser bem quisto. Isso porque a exterioridade tornou-se mais importante que a interioridade. Sábio o aforisma de Epitecto (50-135 d. C.):

Se alguma vez te voltares para as coisas exteriores por desejares agradar alguém, sabe que perdeste o rumo. Basta que sejas filósofo em todas as circunstâncias. Mas se desejares também parecer < filósofo>, exibe-te para ti mesmo, será o suficiente (XENOFONTE, 2012, p.31).

\footnotetext{
7 Vide: São Máximo Confessor (2003, p. 74), acerca do amor-próprio, afirma em Centúrias sobre a caridade e outros escritos espirituais, que o amor-próprio é a mãe de todas as paixões egoístas: “Quem expulsa o amor-próprio, mãe das paixões, afasta igualmente, e facilmente, com a ajuda de Deus, as outras, como a ira, a tristeza, o rancor, etc. Quem, todavia, é vencido pelo amor-próprio, este é atingido igualmente pelas outras, ainda que não o queira".
} 
A exibição de coisas exteriores em função da busca por prestígio é, conforme acima citado, uma perdição. Essa exibição de exterioridades é sintoma do amor-próprio. Epitecto aponta como solução para essa perdição a filosofia, pois ela é a busca pelo conhecimento, especialmente o de si. Para os que querem parecer filósofos devem exibir-se a si mesmos, ou seja, mostrar-se a si mesmo e conhecer-se a si mesmo. Lavelle, acerca da aparência e do ser, afirma:

[...] a negação é a mediação feita entre o ser e o valor, da verdade que nos escapa, quando não nos interrogamos acerca da aparência e da ilusão, do valor que precisa ser desprezado ou violado para que a consciência assim o reivindique e se lance a ele. Vê-se aqui que nem o ser nem o valor podem ser considerados como coisas que nos são dadas. Pois só é possível descobri-los quando o dado deixa de nos satisfazer, e quando buscamos o que o fundamenta e justifica (LAVELLE, 1991, p. 419, tradução nossa).

É na diferença dos valores de l'apparence e de l'etre, que se percebe que o ser é o próprio valor, ao contrário do que pensam os que vivem das aparências. ${ }^{8} \mathrm{Se}$, pois, a consciência é ato e se só é possível se conhecer se expressando, então o eu é uma escolha. Nesse sentido, o autor afirma que o ser e o valor não são dados. É quando não se está satisfeito em ter apenas a aparência que o sujeito se faz e tem um ser (LAVELLE, 2014). Desse modo, compreendemos que, para o filósofo, os valores participam da essência individual. Assim, o indivíduo está se fazendo, tendo sua essência atingido sua plenitude somente na morte.

O primeiro infortúnio de Narciso é preferir mais a projeção que a atuação. Muitas vezes escolhe-se uma fantasia idealizada e deixa de lado o principal que é o dado presente. A projeção, tão covarde, rejeita os dados e opta pela simulação, não tem a audácia da ação. Acerca desse fenômeno adverte Kreeft ${ }^{9} \mathrm{em}$ suas crônicas: "Quando um homem arranja desculpas para não fazer alguma coisa, chegou o momento de fazê-la" (KREEFT, 2017, p. 135). A projeção sempre é um interesse pelo desfrute e nunca pela própria ação em si. Por mais nobre que seja uma ação projetada para o futuro ou lembrada nostalgicamente, seu desfrute fora de hora é indício de um presente desperdiçado. É que o homem não é intrépido o suficiente para aproveitar o agora e as circunstâncias dadas. Por isso aspira às fantasias.

Narciso tem em ato aquilo que projeta como potência. Projetar é exteriorizar o que está dentro. Mas acontece que a projeção que ele vê é fantasiosa. $O$ jovem não percebe que é e idealiza uma potência fora do que se é. É próprio do egoísmo não aproveitar os dados e sempre ambicionar mais insaciavelmente. É insaciável, pois nenhuma projeção do egoísta visa a perfeição em si, mas o desfrute dos resultados da ação, nunca a ação, mas o desfrute. Assim, realizada uma ação exímia, o vaidoso não se contenta enquanto não for enaltecido. Pelo fato de a ação não ser o suficiente ao egoísta, ele nunca se contenta com o presente, pois o presente é a oportunidade de ser, mas não é isso o que ele procura. O futuro, para o vaidoso, é a grande oportunidade do enaltecimento. Assim, mesmo que haja uma ação, é com os olhos no desfrute da mesma que o egoísta se encontra. Todavia, diz Lavelle: "É no presente, portanto, que se acha situado o cimo da nossa consciência" (LAVELLE, 2012, p. 205).

A atuação, conforme o filósofo, requer uma coragem muito grande e demasiado esforço (LAVELLE, 2012). O presente é uma exigência à ação e ao ser. É como se ele dissesse seja, mas Narciso prefere se ter que ser. A ambição está ligada ao futuro não ao presente. Isso porque a

\footnotetext{
${ }^{8}$ Para Lavelle isso não pode ser inferido senão levando em conta que o ser nunca é o ser de uma coisa, mas de um espírito.

${ }^{9}$ O norte-americano Peter John Kreeft é professor de filosofia no Boston College e King's College.
} 
ambição é covarde. Ela não suporta o dado, o presente, mas sempre almeja mais, pois é descontente. Não há vaidade que não seja ambiciosa. Para Lavelle, consoante a Santo Agostinho (354-430), o futuro não existe. O que existe é o agora, ou, como na filosofia de Lavelle: o que existe é o eterno presente. A preocupação com o futuro, de certo modo, é uma distração que nos impossibilita o ser, isto é,o ato.

\section{A divergência entre o egoísmo e o desprendimento}

A ambição é essencial ao amor-próprio narcótico. Ademais, a ambição é adversa ao desprendimento e à indiferença. É no desejo de posse que morre Narciso. Se, em contrapartida, tivesse o jovem sido indiferente ao que tinha ante si, então não teria ele tal desventura. A indiferença, de acordo com Lavelle, é um dos princípios da justiça: "Sabemos bem que "não fazer diferença' é a mesma coisa que ser justo; portanto, é aplicar a todos a mesma regra sem introduzir em nossos julgamentos nenhuma exceção ou nenhum favor" (LAVELLE, 2012, p.110). É, conforme o autor, se estivéssemos vendo tudo sob o ponto de vista de Deus, que olha a todos com um mesmo olhar.

Há, na mística renana (movimento ascético medieval), quem tem um pensamento símil. Mestre Eckhart (1260-1328) considera como maior de todas as virtudes o desprendimento (ECKHART, 2004). Segundo ele, quando o homem é desapegado de tudo, ele se assemelha ao próprio Deus em seu desprendimento. Lavelle é veemente: "Portanto, a indiferença é o remédio do amor-próprio" (LAVELLE, 2012, p. 109). Quando se é indiferente o homem se torna justo em todas as suas ações. E não vê diferença entre as grandes ocasiões e as pequenas. Os acontecimentos mais magnânimos se igualam aos mais humildes. O homem desprendido aproveita todos os momentos igualmente. Tem somente o agora, e nesse agora faz-se a si mesmo. $\mathrm{O}$ desprendido não se volta ao passado ou ao futuro, pois está despreocupado com o desfrute. $O$ apego do qual o egoísta está sujeito é um apego àquilo que ele não é, ao não-ser, ou seja, o egoísta é apegado àquilo que não lhe pertence, e ainda que lhe pertença, o pertence de modo evanescente. É por esse motivo que não deveria haver tal apego: "Só se conhece, só se ama aquilo que não é "si', e Narciso só se interessa por esse conhecimento de si todo alimentado pelo amor de si" (LAVELLE, 1957, p. 137, tradução nossa).

No que concerne ao amor, Lavelle (1957) em Conduite à l'égard d'autrui faz o seguinte questionamento: o amor-próprio é verdadeiramente amor? Após esse questionamento o autor faz esta observação: "Amar é sempre amar um outro e não a si mesmo; então o amor que eu tinha por mim mesmo recua e gradualmente desaparece. Todo amor é uma saída de si, é um apelo a um outro ser" (LAVELLE, 1957, p. 137, tradução nossa). Desse modo, entende-se que todo amor é amor a outro ser e não a si. Podemos explicar isso: é da essência do amor a doação e doação pressupõe um outro:

E há mais: sendo a origem do ato eu não posso ser o objeto. E quando me pergunto como agir sobre mim mesmo, falsifico todas as relações, eu me torno outro para mim mesmo. Volto contra mim um poder que não poderia ser usado nesse sentido e perco-me acreditando servir-me (LAVELLE, 1957, p. 135, tradução nossa).

O que dizer então do amor-próprio se todo amor é para outro ser? Segundo Lavelle (1957) a expressão amor-próprio é uma desonra à palavra amor, pois é uma antítese da lei do amor que é a alteridade. Do fenômeno do egoísmo, dizemos, portanto, que não é amor-próprio, visto que o 
amor não pensa em si mesmo, mas está sempre pronto ao sacrifício. $O$ que podemos deduzir do egoísmo é, de acordo com o que já fora afirmado acima, a sua sujeição ao apego. $O$ homem somente se apega àquilo que é susceptível à perda, e que lhe é alheio. Logo, tudo ao que o homem se apega não pertence ao seu ser, ou, como convém aqui dizer: é uma patologia em relação ao não-eu.

O apego é patogênico. É paixão pelo alheio. O oposto do apego é, como sabemos, o desapego ou desprendimento. Assim não podemos negar que o apego é por consequência antagônico à doação e ao sacrifício. É por isso que o egoísta está preso a seus bens e não é capaz de fazer sacrifícios e não experiencia a doação. Por fim, após essa investigação acerca do chamado amorpróprio percebemos que por meio do desprendimento, do desapego e da indiferença a tudo o que seja evanescente se pode lenir o amor-próprio narcótico, injusto e ilusório. Narcótico porque é vicioso, injusto porque é ávido e ilusório porque se baseia na ficção e não no que é essencial ao seu ser. Desse modo, de acordo com as obras de Louis Lavelle, podemos considerar que para o autor o amor-próprio é uma desordem de uma consciência entorpecida e iludida e também um desencaminhamento do amor que deve sempre voltar-se ao outro e não a nós mesmos.

\section{Considerações finais}

A desordem do amor-próprio, de acordo com o que até aqui estudamos é uma narcose. Visto que é um apego a uma imagem de si que é ilusória. Assim, para uma verdadeira consciência de si, é preciso se desapegar dessas fantasias. Se o desprendimento é o remédio para o egoísmo isso significa que o objeto principal e único a ser desapegado é a si mesmo. O desapego, ao contrário do que se pensa, não deve ser um desapego aos bens. Eles são imprescindíveis. Todavia, o homem despojado das posses na realidade é desprendido de si mesmo, o desprendimento às coisas vem por consequência. O que mais importa e é mais valioso ao egoísta é o ego. Por isso, o egoísta não se doa aos outros. Pobre Narciso, quis ele próprio desfrutar-se de si. Não percebeu que a doação, isto é, o amor é a principal lei da humanidade e que o homem não foi feito para si, pois é contra a natureza do amor o voltar-se a si mesmo em deleite.

Quando se crê que se ama si próprio, em conformidade com o autor, na verdade se ama uma fantasia de si, e não o seu ser real, pois para se amar é preciso se duplicar e isso rompe a unidade do eu: o eu manifesto que é o imaginado, e o eu real, onde está a consciência. O problema dessa simulação é que o eu que deve ser conhecido é o eu real, ou seja, é a própria consciência. E essa consciência de si não se dá por analise, mas sim ao se fazer, pois o eu não é um feito ou memória, mas é o ato pelo qual ele se cria. A consciência não é memória de um passado ou de um ocorrido, mas é ação, em um eterno presente. Dessa forma, quando se tem uma imagem de si, que sempre é baseada no passado, e se acredita que ela é o eu, se está enganado.

Acontece muitas vezes de o amor-próprio macular ainda mais essa imagem de si que já não é real. Como se não bastasse, o amor-próprio dá um sentimento de satisfação com a imagem de si, como se o eu já tivesse alcançado a perfeição, paralisando assim a potência de criar-se, e isso só deveria acontecer na morte. $\mathrm{O}$ eu, sendo desejo, se realiza saindo de si, na busca pelo Ser que ele ainda não é. Desse modo, podemos entender que o amor-próprio é uma desordem pelo fato de que é uma ilusão, dado que o amor é para o outro, é um sair de si. 


\section{Referências}

ARISTÓTELES, Ética à Nicômaco, 1. Ed. São Paulo: Atlas, 2009.

BÍBLIA - Edições CNBB. Brasília- DF: Editora Canção Nova, 2012.

ECKHART, Mestre. Sobre o desprendimento e outros textos; tradução do médio-alto alemão Alfred J. Keller. - São Paulo: Martins Fontes, 2004.

KREEFT, Peter. Como vencer a Guerra Cultural: um plano de batalha cristão para uma sociedade em crise. Campinas, SP: Ecclesiae, 2011.

LASCH, Christopher. A cultura do narcisismo. Rio de Janeiro: Imago Editora, 1983.

LASCH, Christopher, Louis. A consciência de si, Ed: 1. São Paulo: Editora É Realizações, 2016.

LASCH, Christopher, Louis. Carnets de guerre. Québec : Les Éditions du Beffroi;

Paris : Société d'Édition Les BellesLettres, 1985, 404 pp.

LASCH, Christopher, Louis. Conduite à l'égard d'autrui. Paris : Éditions Albin Michel, 1957, 246 pp.

LASCH, Christopher, Louis. De l'Acte. Paris : Fernand Aubier, aux Éditions Montaigne, 1946, 541 pp. Collection : Philosophie de l'esprit. "La didactique de l'éternel présent."

LASCH, Christopher, Louis. Introduction à l'ontologie. Paris : Les Presses universitaires de France, 1951, 135 pp. Collection : Nouvelle encyclopédie philosophique. 1re édition, 1947. 2e édition, 1950.

LASCH, Christopher, Louis. O erro de Narciso. Ed: 2. São Paulo: Editora É Realizações, 2016.

LASCH, Christopher, Louis. Regras da vida cotidiana; tradução Carlos Nougué. - São Paulo: É Realizações, 2011.

LASCH, Christopher, Louis. Traité des valeurs. Théorie générale de la valeur. Paris : Les Presses universitaires de France, 1re édition, 1950, 2e édition, 1991, 753 pp. Collection : DITO.

MÁXIMO, São. Centúrias sobre a caridade. São Paulo, SP: Editora Landy, 2003.

OVÍDIO. Metamorphoses. Raimundo Nonato Barbosa de Carvalho. Universidade de São Paulo, Faculdade de Filosofia, SP: 2010.

PADILHA, Tarcísio. A ontologia axiológica de Louis Lavelle. São Paulo: É Realizações, 2012. PLATÃO, Diálogos. 1. Ed. Baurú, SP: Edipro, 2007.

XENOFONTE, Lúcio Flávio Arriano. Bilíngue. São Cristóvão. Universidade, Encheirídion de Epicteto. Edição Federal de Sergipe, 2012.

Contribuição dos(as) autores(as) / Author's Contributions:: As contribuições de José Aparecido Pereira estão relacionadas à redação, correções, definição e elaboração do objeto de discussão do artigo, análise da fundamentação teórica e estruturação lógica do texto. As contribuições de Harlon Luan dos Santos estão ligadas à redação do texto, levantamento bibliográfico, tradução do francês para o português e definição do objeto de discussão do artigo. Ambos aceitaram e aprovaram a versão final do texto.

Autor(a) para correspondência / Corresponding author: José Aparecido Pereira. aparecido.pereira@pucpr.br 